\title{
Portugal: the fall of the fascist regime as seen through political poster design 1945-1975
}

A poster made by the fascist regime of the Estado Novo [c. 1935] illustrates perfectly the regime's boastful pretension that Portugal was a European imperial power. But if the claim that the poster revealed elements of truth in the 1930 s and 1940s, when Portugal's grip on its "Overseas Provinces" (as they were then styled) was relatively secure, it began to break down, mainly during the 40's.

Starting from this reference point, the paper aims to 'illustrate' a narrative about the slow fall of the regime (1926-1974) seen through political poster design based on visual rhetoric, thereby providing a visual analysis of existing posters in Portugal from 1945 until 1975 (one year after the revolution). The paper presents the dominant aspects in realizing a poster from the perspective of the programme, authorship and technology. The programme as a cultural mediator is conveniently interpreted through authorship. In this analysis, it is also revealed that the preponderance of political images and text messages included in the posters enable the perception of how/what was used as a visual iconography. Furthermore, the paper will explain the political constraints and proposals relating to the production and reproduction of posters. Regarding authorship, this paper seeks to reveal the extent to which the author/artists were recognised and appreciated. Interpretation will also be made of the visual motifs selected by the author/artists, together with an understanding of the knowledge communicated in their configuration. Moreover, in addition to the processes involved in design practice, the paper seeks to identify the technologies involved in the reproduction of posters through the selection and use of particular technologies when the poster were created.

Consequently, the paper aims to contribute to design historical knowledge through analysis of political poster opposing the regime of the dictatorship of Oliveira Salazar (1889-1970).

keywords political posters, design history, dictatorship, Estado Novo

\section{Introduction}

Despite the date of the Estado Novo poster that was trying at all cost to demonstrate the immensity of its 'empire', over the following decades, the regime found itself unable to maintain the idyllic crystallized image of itself as a great unified nation with vastly dispersed territory (fig.1). In this poster, in addition to the image, which intentionally illustrates the political ideology that predominated throughout that period and in 
theme 2

memory

Figure 1.

Portugal it isn't a small country [c.1935]. Lithography. $97.5 \mathrm{~cm} \times 69 \mathrm{~cm}$ strand 1

design histories: tradition, transgression and transformations

subsequent years', the text presents a series of topics that reinforce this purpose.

Subtitled "Superfície do império colonial português" ("Surface of the Portuguese colonial empire") and organized by Henrique Galvão (1895-1970)², it offers some numerical data about the Portuguese territories, namely that the combined area of Portugal, the Azores, Madeira, Cape Verde, Guinea, S. Tomé and Príncipe, Angola, Mozambique, the State of India, Macau and Timor was 2,168,071 Km2 compared to a mere 2,096, $639 \mathrm{Km} 2$ for Spain, France, England, Italy and Germany put together). Thus, with this artefact, the Estado Novo was trying to demonstrate its territorial and patriotic reach both nationally and internationally. This paper will focus on the transformation of the ideals of political regime and the public sphere through political poster.

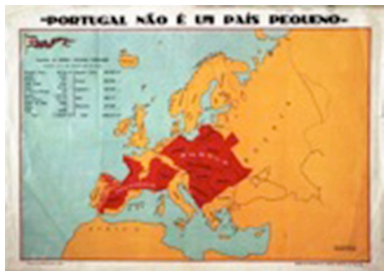

\section{From an ideal of Portuguese territory to a new reality}

In order to take advantage of the persuasiveness of the poster as a genre, the political power during the 1940 s had to choose a different visual communication strategy in relation to the previous decade. Though it continued to print large-format posters ${ }^{3}$, the palette was now restricted to two colours, and long detailed texts, animated by typographical variation, began to take over from images. Consequently, typography started to be used instead of lithography.

Considering the low literacy level in the country, what could have been the reason for this change of strategy when an image is worth more than 1000 words?

The change occurred basically for three reasons. The first had to do with the loss of artists involved in the production of political posters. Many of those that had previously contributed to the construction of the regime's image ${ }^{4}$ gradually began to distance themselves in this decade. This is perceptible in an anonymous campaign poster entitled "Artists! Intellectuals" (1945), which announces a series of cultural initiatives and denounces the disaffection of artists towards the political power: "A whole work of renovation and revelation of values which artists have taken advantage of, including some that today proclaim themselves enemies of the Estado Novo".

\footnotetext{
1"The nationalist atmosphere, which the 28th May [1937] commemoration would have made more emotional for the population, would necessarily have awakened in the Portuguese a greater awareness of the situation in the overseas territories in the defence of the territorial unity of the metropolis and the overseas possessions" (Serrão 2000:122).

${ }^{2}$ The initially fervent support for the regime became strong opposition to it from the 1950s onwards. ${ }^{3}$ On average, they ranged from $50 \mathrm{~cm}$ to $100 \mathrm{~cm}$ (minimum and maximum dimensions).

4 They were animated by the writer, journalist and politician António Ferro (1896-1956) who had been close to the modernists since the 1920 s and became a consensual figure amongst artists. His political approximation to the Estado Novo became clear when he took over the direction of the Secretariat for National Propaganda (1933), requesting the participation of artists in poster creation, interior design for national and international exhibitions, book covers, catalogues and magazines (Barbosa 2012: 7).
} 
The second reason lies in the specific nature of the information, the contents of which would have been difficult to illustrate. This can be seen in another campaign poster, by an unknown artist, entitled "Vote for Salazar!" (1945), which solicits gratitude and votes for having saved the Portuguese people from participation in the $2^{\text {nd }}$ World War. Amongst other things, it gives data about the number of deaths in Czechoslovakia, France and Central Europe, contrasting this with the statement: "You have a home; Your children are alive; You have shelter and You have bread". Hence, the posters of this period have basically begun to transmit subjects instead of concepts.

The third motive has to do with the investment required to produce posters. Lithography was not only time-consuming, it was also expensive, unlike typography. The political machine was reluctant to spend funds unnecessarily on this 'discourse of persuasion' when it could use repression and violence to maintain control. Despite these measures, the poster nevertheless reveals the desperation and weakening of the political power.

\section{Dissident visual manifestations in the construction of an opposition leading to the fall of the Estado Novo}

The imperialist ideal gradually succumbed before the policies of the fascist regime that were becoming increasingly unpopular. For various reasons, attention was being drawn to the persecutions perpetrated by the political police (Polícia Internacional e de Defesa do Estado or PIDE, 1945-1969)5 which prevented freedom of expression, generating enough opponents to gradually create a structured opposition which grew stronger and more representative over time.

This was manifested in the presidential elections of the forthcoming years, when a series of opponents ${ }^{6}$ stood against the regime: in 1949, there was Norton de Matos (1867-1955) who stepped down some days before the elections; in 1951, Admiral Quintão Meireles (1880-1962), also obliged to step down; and in 1958, General Humberto Delgado (19061965) who was defeated by electoral fraud and subsequently killed by the PIDE. How did the electoral posters of the opposition propose and illustrate an alternative to the regime?

These candidates' posters differ from those of the fascist regime in the configuration of the image and message of the text. In the case of Norton de Matos, all the posters are anonymous except for one signed by the artist Júlio Pomar (1926- ), which reveals not only a manifest interest in actively participating and contributing to a change of regime, but also in the presentation of a different simpler aesthetic. The bust of the politician is compactly drawn in a single colour, occupying almost the entire surface of the white sheet. In contrast, the text, which reads "General Norton de Matos, candidate to the President of the Republic", is timidly compressed into the left-hand side of the sheet, having been typewritten and stencilled at approximately A4 size. This politician had few resources to invest in the reproduction of posters, as can be seen with a poster of $15 \mathrm{~cm} X 9 \mathrm{~cm}$, printed typographically in black, which only announced the following message: "Apoiar Norton de Matos é lutar pela democracia" "To support Norton de Matos is to fight for democracy"). The brevity of this information contrasted with the posters produced by the "Aveiro Independent Committee" (his supporters), which were like pages

\footnotetext{
5 Indeed, the year that this organism was created reflects the Estado Novo's insecurity about controlling the country.

${ }^{6}$ Previously they had held posts in the Salazar regime.
} 
theme 2

memory

Figure 2.

The Republic needs you. Vote in Norton de Matos (1949).

Lithography. $47 \mathrm{~cm} \times 65 \mathrm{~cm}$. strand 1

design histories: tradition, transgression and transformations

of a book in composition. Printed typographically in blue or black, these posters with their dense text sought to attract the attention of the public using different types, without being excessively ornamented. In some cases, the composition is very similar to the political posters of the $19^{\text {th }}$ century. Many of these posters were "Vetted by the Censorship Board", indicating the control that the regime exerted over poster production while at the same time attempting to demonstrate some political transparency. One red and black poster shows the female figure of the Republic in large scale, transmitting the idea of the nation (fig. 2). The dynamic composition, manifested particularly in the figure's arm and hand gestures and piercing gaze, reinforces the urge to vote, complemented by the message "The Republic needs you", though the image ${ }^{7}$ is strangely proportioned, revealing the artist's lack of mastery at drawing. In this case, the persuasiveness is achieved not by conventional female seductiveness but by the figure's intimidating gesture and expression, inciting political change.

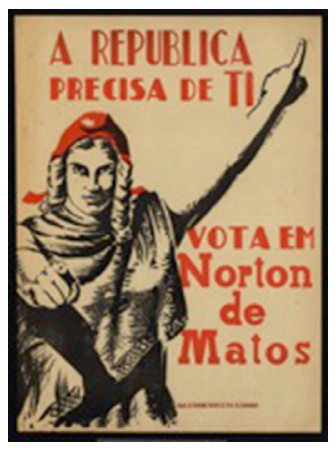

Only one poster has been found from Quintão Meireles' presidential campaign, ${ }^{8}$ $60 \mathrm{~cm} \times 90 \mathrm{~cm}$, showing a framed half-body photograph in black and white, with graduated shading between the green and red, representing the colours of the national flag. With its focused gaze and slight rotation of the body to the right, the image suggests that the candidate is prepared to confront all problems, evoking security and personifying a certain paternalism. The idea of the state is transmitted not only by the candidate's body but also by his military uniform and political pose, which make him seem imposing; despite the crossed arms, the image is of a fearsomely efficient and dynamic president. The four lines of text ("Vote for Admiral Quintão Meireles"), drawn in different styles, underline this dynamism, reinforced by the calligraphy, which slopes upwards in the first word.

Humberto Delgado's posters used other means of visual communication, limited by a lack of funds. They were around A4 size and printed in black (a domain in which offset and typography predominated), sometimes on coloured paper to enable them to stand out in public spaces (fig. 3).

In order to achieve greater visibility, a considerable number of copies were printed by the standards of the period (3000)9. As a result of these constraints, the visual rhetoric is distinct, using techniques that range from photo-reportage to long verbal texts, laid

\footnotetext{
7 This is reminiscent of Alfred Leet's war poster (1914).

${ }^{8} 5000$ copies were printed.

${ }^{9}$ This figure is close to the print runs used by the Estado Novo (which also produced much larger posters).
} 
out like a newspapers or other such publication. Those that use photo-reportage divert the gaze from the politician to his supporters, and frame to the shots so that the appear numerous, as well as humanizing the politician in their midst. Though there has been no transformation as regards the configuration of these images, as occurred with the previous example, they are designed to demonstrate leadership and followers. They are posters that bear witness to events that have already occurred, projecting the politician's greatness as someone able to mobilize multitudes with his eloquent speeches, while also transmitting calmness and openness to the integration of new supporters. These posters suggest a cluster of possibilities in which the onlookers become part of history, where there is collective participation, and where the crystallization of those photographic images announce their importance, multiplied by the printing of posters affixed in the streets.

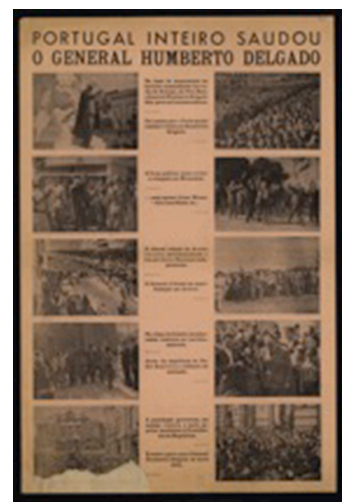

Figure 3 . All Portugal saluted the General Humberto Delgado (1958). Offset.

This enthusiasm meant that there were fewer sympathizers with the fascist regime and enhanced the representativity of dissident and opposition posters, which increased in number from 10,000 copies in the 1960 s to 250,000 in 1975. These were large-scale and printed in offset and serigraphy ${ }^{10}$, and were disseminated widely around the streets, bearing messages of change and demands for a new democracy. This was the voice of the people determined to unseat the regime using the poster to express their wishes. The visual aspect of those posters contrasts markedly with earlier ones. And while they remained anonymous in the 1960s, this was not the case in the following decade, when artists actively participated in in the construction of freedom of expression. Amongst them were Abel Manta (1928- ), Carlos Rocha (1943- ), Marcelino Vespeira (1925-2002), Sebastião Rodrigues (1929-1997) and Vieira da Silva (1908-1992). Now the central figure of the politician disappears and we get instead images of the people, symbols of the party and other icons, like the clenched fist, hammer, sickle and carnation. The palette centres around yellow, red, orange and black. These aspects, which of course are highly significant, are evidence of a new visual language based on collective imagery which at the same time characterizes the common interests of the politicians and the public. This is the visual rhetoric of posters of the Revolution.

\footnotetext{
10 This printing technology was widely used in this period due to the persecutions that took place in the divulgation of posters. The Censorship Board was losing control of poster publication, just as the PIDE was losing control over the opposition's activities. Serigraphy was an accessible 'cottage'-type technology, which permitted the clandestine printing at no great risk or cost.
} 


\section{Conclusion}

These posters reflected the perception that the Estado Novo was experiencing problems, and these signs become visibly more important from the 1940 on onwards. While these policies contributed to the rupture of the imperialist ideal, both internally and externally, with the loss of the colonies after the revolution of $25^{\text {th }}$ April 1974, the signs of formal language presented synchronically revealed different concepts (signifieds) in the creation of political images (signifiers), considering that it was constituted from diverse references, revealing coherence of meaning and in the purpose to be achieved. The poster as an artefact and bearer of messages (image and text) was able to help bring about the desired change. A parallel study is now required of poster production in the Portuguese colonies in order to understand how visual rhetoric was manifested between the 1940s and ' 70 in those countries.

\section{References}

Barbosa, H. (2012) 'The design of Portuguese posters for sport from late 19th Century until the end of the 2oth Century,', in Design History Society Conference (ed.) The material culture of sport: design, history, identity, Brighton: University of Brighton.

França, J. A. (1991) A arte em Portugal no século XX, Vol. III, Lisboa: Bertrand Editora. Serrão, J. V. (2000) História de Portugal, Vol. XIV, (2003) Vol. XV, (2006) Vol. XVI, (2007) Vol. XVII, Lisboa: Verbo.

\section{Acknowledgements}

This work is funded by FEDER through the Operational Competitiveness Programme COMPETE - and by national funds through the Foundation for Science and Technology - FCT - in the scope of project PTDC/CPC-DES/4754/2012 (FCOMP-01-0124-FEDER-028530)

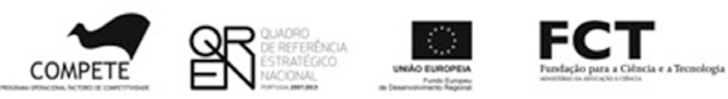

